\title{
Evaluation of alternative institutional arrangements in public utilities
}

\author{
Anna Ermishina, ${ }^{1, *}$, and Elena Mienshenina ${ }^{2}$ \\ ${ }^{1}$ Southern Federal University, Economic Faculty, Rostov-on-Don, Russia \\ ${ }^{2}$ Don State Technical University, Road Transport Engineering Faculty, Rostov-on-Don, Russia
}

\begin{abstract}
Since the early 2000s a policy of attracting private operators to public utilities, which should help to increase productivity, reduce costs, and as a result, reduce utility prices, takes place in Russia. The aim of the study is to identify the relationship between institutional arrangements and pricing of water and sanitation services. Statistical and cluster analysis was applied to empirical data on water utilities in the 13 largest cities. There were the differences in the level and dynamics of prices for water supply and sanitation in the group of public utilities and public private water utilities.
\end{abstract}

\section{Introduction}

Around the world a search for the alternatives to the institutional arrangements of the municipal economy, which are allowing to provide accessibility and affordability of public utilities services for the majority of the population and the economic efficiency of the utilities, remains relevant. Water supply and sanitation sector is one of the largest of Russia's public utility industries. At the end of XX - the beginning of XXI centuries the reform of the water supply was inspired by the world practices. The experience of the developed European countries in the sphere of production, financing and water provision services was used to form the basic tenets of the reform. The most famous models among Russian scientists and industry professionals are conventionally called "English", "German" and "French" models. They got the titles in accordance with the names of the countries in which these models were widely disseminated.

The "English" model of water supply, developed in the UK, involves the complete privatization of municipal infrastructure in combination with the state regulation of tariffs for water and sanitation services. The "German" model is characterized by a high participation degree of the local authorities as in the price control, so in the production and provision of these services. Municipalities create joint ventures with operators in the form of open joint stock companies (OJSCs). The water supply infrastructure is included in the authorized capital stock as a contribution of the municipality that controls the majority of shares. The "French model" has spread in France. It involves the transfer of the municipal property, owned by the municipality, from the local authorities to the management of a private company on the basis of long-term (30-35 years) concession agreement. Investor's ownership of property and newly created objects are terminated upon the expiration of the concession [1].

The ideologists of the Russia's water supply reform came to the conclusion that the most effective model would be the "French" one in Russia. This water supply organization attracts private business and private investment to the municipal economy and, at the same time, allows controlling the production of socially significant services through the infrastructure, which remains in municipal ownership [2].

Each of the institutional alternative arrangements has its advantages and disadvantages. An indirect measure of economic and social efficiency is the cost of public resources and its dynamics. Many services (including water and wastewater services) are produced in conditions of a natural monopoly in the local economy. The unregulated natural monopoly is a situation of the market inefficiency, which overestimates optimal prices and reduces the socio-effective production. The regulation of natural monopolies aims breaking the power of monopolies to set higher prices. These measures should, in general, improve the economic efficiency of the municipal economy. In addition, the regulated tariff for communal services is the most important indicator, which shows service's affordability for the majority of the population and ensures the effectiveness of the social sector.

In the last decade the regulated tariffs for housing and communal services are growing rapidly, many times ahead of inflation in Russia. At the same time the deterioration of networks remains high, that increases the risk of accidents and reduces the quality of service. To improve service quality and to attract investments a policy of attracting private operators to the industry is held in Russia from the beginning of the 2000s. More efficient operations in terms of public-private partnership should cause an increase in productivity in the industry, 
costs reduction, and as a consequence, reduction of tariffs for water and wastewater services.

\section{Brief literature review and goal of the research}

In the foreign literature the operation results of the various institutional alternative arrangements of the municipal economy are actively studied. However, only a small number of empirical studies are devoted to the study of the relationship between institutional options for municipal economy and water tariffs.

S. Garcia et al. examined the influence of technical factors, competition and company's strategy on the water prices in France [3]. Their studies show that the strategy of the utility operator companies has a significant effect on the price level. D. Hall and E. Lobina empirically show that the privatization of the water supply companies sometimes leads to unjustified price increases $[4,5]$. E. Chong et al. have also shown the example of the water supply in France, where the choice of any form of public-private partnerships instead of the direct state / municipal government is likely to lead to an increase in the cost of the urban water supply services [6].

A. Carpentier et al. compared the public and the private water utilities organization in France [7]. He found that the prices are higher in the private management, because private operators are faced with a tough environment. In addition, this article concludes that the desire of the local authorities to privatize urban water supply services is driven by a technical complexity of their maintenance. R. Martinez-Espineria et al. also found that privatization lead to an increase in the price of water in the large urban Spanish municipalities [8]. S. Zschille and M. Ruester examined the relationship between the forms of management in the water-supply German companies and prices paid by consumers (controlling economies of scale and technical and structural characteristics of the water utilities) [9]. The main conclusion of this study is the fact that the involvement of the private sector causes an increase in water prices [9].

Studies of V.M. Garcia and others examined the relationship between the various institutional arrangements of municipal economy and the level of the urban water prices for the population [10]. The experience of municipalities in southern Spain (province of Andalusia) is described in the article. The form of the water supply management, which leads to the lowest prices for water, was the provision of services by the municipality. The Urban Water Supply Company, managed by the private operators under contract, took the second place. But municipal enterprises, according to the study, charge higher prices than utility companies with the participation of the private sector [10].

In recent years Russia's state policy in the municipal sector, on the one hand, aims the formation of the business environment through the development of the privatization processes and the use of public-private partnership (PPP). On the other hand, issues in the tariff regulation are fixed at the federal level, while it is one of the major risk factors for attracting investment in the municipal sector. In Russia there are unitary enterprises with a state or municipal property and private operators (OJSC, LLC with a share of private ownership), which exist in the form of the public-private partnership. The bulk of the production and delivery of the water services are provided by municipal unitary enterprises. The share of other forms accounts $26.6 \%$ of the total release of water to the population, more than two thirds is provided by private organizations, $1 / 5$ of the water supply infrastructure and sanitation is in lease or concession (19.4\% - in lease, $0.6 \%$ - in concession).

An analysis of the privatization process in Russia's water and sanitation sector reveals the following distinctive features:

- long-term leases (25-49 years) are close to the classic concession contract;

- private operators work mainly on the long-term lease contracts with investment liabilities;

- the absence of public debate during the competitions and determining the contract conditions;

- trade unions and social organizations of consumers are not represented as a part of the negotiating parties;

- large interregional companies, which are affiliated with the businesses in other sectors, act as tenants;

- tenants are interested, as a rule, in large facilities of cities;

- tenants carry out a significant part of the investment from the state budget [11].

- In addition, according to experts, the PPP in the water supply is characterized by the following facts:

- indicators have improved, but there is no conclusive evidence of the private operators benefits compared to the water supply services as a whole;

- institutional and legal conditions of the organizations are improving, but they are still insufficient for the implementation of concession agreements;

- there are still high barriers to entry into the market of international private operators [12].

The problem needs more qualitative empirical studies of the economic and institutional changes during the reforming process of housing and communal services. Studies on the influence of institutional factors to the results of the tariff policy in the industry are completely absent.

The aim of our research is the development and testing some methodological approaches for the empirical evaluation of the effectiveness of various institutional alternative arrangements. The main purpose is achieved by identifying the relationship between the forms of management and the tariff policy in the water supply sector in Russia. 
Table 1. The Russia's largest water utilities.

\begin{tabular}{|l|l|l|l|}
\hline № & \multicolumn{1}{|c|}{ City } & Population & \multicolumn{1}{c|}{ Name of the water supply organization } \\
\hline 1 & Novosibirsk & 1547910 & MUP "Gorvodokanal "[13] \\
\hline 2 & Ekaterinburg & 1412346 & MUP "Vodokanal" [14] \\
\hline 3 & Nizhny Novgorod & 1263873 & OJSC "Nizhny Novgorod Vodokanal" (since 2006) [15] \\
\hline 4 & Kazan & 1190850 & MUP "Vodokanal" [16] \\
\hline 5 & Samara & 1172348 & MP "Samaravodokanal" (until 2011); LLC "Samara Municipal Systems" (since 2011) [17] \\
\hline 6 & Chelyabinsk & 1169432 & MUP "POVV" [18] \\
\hline 7 & Omsk & 1166092 & OJSC "OmskVodokanal" (since 2005) [19] \\
\hline 8 & Rostov-on-Don & 1109835 & OJSC "PO Vodokanal" (since 2004) [20] \\
\hline 9 & Ufa & 1096702 & MUP "Ufavodokanal" [21] \\
\hline 10 & Krasnoyarsk & 1035528 & LLC "KrasKom" (2003) [22] \\
\hline 11 & Perm & 1026477 & LLC "Novogor-Kama" (2003) [23] \\
\hline 12 & Volgograd & 1017985 & MUP "Gorvodokanal Volgograd" [24] \\
\hline 13 & Voronezh & 1014610 & MUP "Vodokanal Voronezh" (2012), LLC "RKS-Voronezh" "(since 2012) [25] \\
\hline
\end{tabular}

a MUP - Municipal Unitary Enterprise

b MP - Municipal Enterprise

\section{Brief literature review and goal of the research}

Thirteen major cities of Russia (with a population of over one million people) were chosen to investigate the influence of the management utility on the level and dynamics of tariffs for water supply. The leading manufacturers of the water supply services in the cities are the country's largest water utilities; in fact they are local monopolists in megacities (Table 1).

On 1 January 2014 the municipal water utilities served six of the largest cities of Russia, and the seven largest cities were served by the water utilities organized as a shared ownership with private operators. In all cities at different periods of time private capital was involved. Krasnoyarsk and Perm were ones of the first in Russia, where the private management of water and wastewater networks is carried out since 2003. In Rostov-on-Don, Omsk private operators manage the infrastructure of the water supply services since 2004-2005. Cities with the little experience of the private operating in the water supply are Samara (since 2011) and Voronezh (since 2012). Thus, for more than five years there are private operators in most of the largest cities in Russia.

For the research the tariffs for water supply and sanitation over the past five years in the cities, which are served by the water utilities with a variety of institutional options for utilities is needed to compare.

Table 2 shows the tariffs for the water supply and sanitation in the dynamics in major Russian cities for the last five years.

Table 2. Water and sanitation tariffs in the major cities of Russia in 2010-2014, Rub./ $\mathrm{m}^{3}$.

\begin{tabular}{|c|c|c|c|c|c|}
\hline & 2010 & 2011 & 2012 & 2013 & 2014 \\
\hline MUP "Gorvodokanal" (Novosibirsk) & 14.22 & 21.3 & 20.09 & 23.78 & 23.78 \\
\hline MUP "Vodokanal" (Ekaterinburg) & 27.52 & 31.56 & 35.52 & 40.05 & 40.05 \\
\hline MUP "Vodokanal" (Kazan) & 22.78 & 23.51 & 26.06 & 27.13 & 29.61 \\
\hline MUP "POVV" (Chelyabinsk) & 18.87 & 20.46 & 21.7 & 24.3 & 27.57 \\
\hline MUP "Ufavodokanal" & 14.77 & 17.04 & 22.51 & 24.05 & 24.05 \\
\hline MUP "Gorvodokanal Volgograd" & 21.36 & 20.92 & 23.18 & 25.18 & 29.1 \\
\hline MUP "Vodokanal Voronezh" & 21.69 & 23.34 & 27.54 & & \\
\hline LLC "RKS-Voronezh" & & & & 30.25 & 40.79 \\
\hline MP "Samaravodokanal" & 17.56 & 21.64 & & & \\
\hline LLC "Samara Municipal Systems" & & & 23.15 & 27.45 & 27.45 \\
\hline JSC "Nizhny Novgorod Vodokanal" & 16.14 & 22.38 & 20.38 & 23.94 & 23.94 \\
\hline JSC "OmskVodokanal" & 19.51 & 20.95 & 25.58 & 30.23 & 32.72 \\
\hline OAO "PO Vodokanal" (Rostov-on-Don) & 29.35 & 44.69 & 48.6 & 58.12 & 58.03 \\
\hline Ltd. "KrasKom " (Krasnoyarsk) & 16.42 & 18.14 & 20.39 & 22.59 & 22.59 \\
\hline Ltd. "Novogor-Kama" (Perm) & 43 & 33.77 & 31.23 & 33.19 & 36.12 \\
\hline Correlation & 0.22 & 0.28 & 0.19 & 0.25 & 0.28 \\
\hline
\end{tabular}

Source: Calculated by the authors according to the official pages of the companies 


\section{Results}

In 2010-2014 in the group of the municipal water utilities Yekaterinburg was a leader in terms of tariffs. And Vodokanal of Rostov-on-Don with the tariffs higher by $41-56 \%$ than tariffs in Yekaterinburg took the first place in the group of non-public operators. In the group of private operated water utilities average tariffs were also higher by $11-19 \%$. During the $2010-2014$ 's there was a positive moderate correlation (0.19-0.28) between the forms of the management utilities and tariffs for services. In the group of private management utility prices are higher on average than in the municipal unitary enterprises. The results of the tariff dynamics analysis in the Russia's largest cities are shown in Table 3.

In cities with a municipal form of management there was the highest growth of rates in comparison with the previous year in Novosibirsk in 2011 (it amounted to $49.79 \%$ ). The following year rates decreased 5.68\%, however the overall increase in tariffs for the water supply services for five years was $67.23 \%$ in
Novosibirsk. And it was also the highest in the group of municipal water utilities.

In the group of the cities where the water and wastewater services are provided by operators with a share of private ownership, the greatest increase in tariffs compared to the previous year took place in Rostov-onDon: water utility service tariffs were raised by $52.28 \%$ compared with the previous 2011. Rostov-on-Don is the leader in rising tariffs for five years (97.72\%). In Voronezh the significant growth of tariffs for the water supply services was observed after changing the form of management to a private operator LLC "RKSVoronezh". In Voronezh overall 5-year growth of rates was more than $88 \%$. However, there is a water utility in Perm in this group, which has reduced tariffs by more than $21 \%$ in 2011. And tariff reduction of LLC "Novogor-Kama" has amounted to $16 \%$ for five years. It is the only enterprise tariff dynamics which differs from all other water utilities in both groups. Overall, however, during 2011-2014 a faster increase in water tariffs was observed in the non-public water utilities than in the municipal water utilities in the largest cities of Russia.

Table 3. The dynamics of water and sanitation tariffs in the largest cities of Russia in the period from 2011 to $2014, \%$.

\begin{tabular}{|c|c|c|c|c|c|}
\hline & $2011 / 2010$ & $2012 / 2011$ & $2013 / 2012$ & $2014 / 2013$ & $2014 / 2010$ \\
\hline \multicolumn{6}{|c|}{ Municipal Unitary Enterprises } \\
\hline $\begin{array}{l}\text { MUP "Gorvodokanal" } \\
\text { (Novosibirsk) }\end{array}$ & 49.79 & -5.68 & 18.37 & 0 & 67.23 \\
\hline MUP "Vodokanal" (Ekaterinburg) & 14.68 & 12.55 & 12.75 & 0 & 45.53 \\
\hline MUP "Ufavodokanal" & 15.37 & 32.10 & 6.84 & 0 & 62.83 \\
\hline MUP "Vodokanal" (Kazan) & 3.20 & 10.85 & 4.11 & 9.14 & 29.98 \\
\hline MUP "Gorvodokanal Volgograd " & -2.06 & 10.80 & 8.63 & 15.57 & 36.24 \\
\hline MUP "Vodokanal Voronezh" & 7.61 & 17.99 & & & \\
\hline MUP "POVV" (Chelyabinsk) & 8.43 & 6.06 & 11.98 & 13.46 & 46.10 \\
\hline MP "Samaravodokanal" & 23.23 & & & & \\
\hline \multicolumn{6}{|c|}{ Operators with a share of private property } \\
\hline LLC "RKS-Voronezh" & & & 9.84 & 34.84 & 88.06 \\
\hline $\begin{array}{l}\text { OJSC "PO Vodokanal" (Rostov- } \\
\text { on-Don) }\end{array}$ & 52.27 & 8.75 & 19.59 & -0.15 & 97.72 \\
\hline \begin{tabular}{|l|} 
OJSC "Nizhny Novgorod \\
Vodokanal" \\
\end{tabular} & 38.66 & -8.94 & 17.47 & 0 & 48.33 \\
\hline LLC "Samara Municipal Systems" & & 6.98 & 18.57 & 0 & 56.32 \\
\hline LLC"paint" (Krasnoyarsk) & 10.48 & 12.40 & 10.79 & 0 & 37.58 \\
\hline LLC"Novogor-Kama" (Perm) & -21.47 & -7.52 & 6.28 & 8.83 & -16.00 \\
\hline OJSC "OmskVodokanal" & 7.38 & 22.10 & 18.18 & 8.24 & 67.71 \\
\hline
\end{tabular}




\section{Conclusion and discussion}

Thus, the involvement of private capital to the Russian utility sector has not yet led to the expected positive change of the tariff policy. In 2010-2014 the level of tariffs and their dynamics in the group of the water utilities, which are involving private capital was higher than in the water utilities with the municipal form of management in Russia's largest cities. Perhaps tariffs for services of the water utilities managed by the private operators increased due to the development and implementation of investment programs in the largest Russian cities. Other factors should be taken into account, so that creates prospects for the further research. It may be interesting to investigate the results of the private capital, which is attracted to the Russian communal economy, and the effectiveness evaluation of the various institutional arrangements in the municipal economy. However, Perm's example gives a hope for the formation of positive expectations regarding the tariff policy of the water utilities controlled by using a model of public-private partnership.

\section{References}

1. V.G. Varnavskiy, A.V. Klimenko, V.A. Korolev, Publicprivate partnership. Theory and practice (Publ. House SU HSE, Moscow, 2010)

2. A.V. Ermishina, Proc. DNTU. Ser.: econ., 38-1, 193-203 (2010)

3. S. Garcia, L. Guerin-Schneider, G. Fauquert, Water Supply, 5(6), 173-181 (2005)

4. D. Hall, E. Lobina, Natural Resources Forum, 28, 268-277 (2004)
5. E. Lobina, Water Resources Development, 21(1), 55-87 (2005)

6. E. Chong, F. Huet, S. Saussier, F. Steiner Rev. of Ind. Org. 29 (1/2), 149 - 169 (2006)

7. A. Carpentier, C. Nauges, A. Reynaud, A. Thomas, Economie et Prevision, 174(3), 1-20 (2006)

8. R. Martinez-Espineira, M.A. Garcia-Valinas, F. GonzalezGomez, Urb. Stud., 46(4), 923-945 (2009)

9. S. Ruester, M. Zschille, Utilities Policy, 18(3), 154-162 (2010)

10. M.A. García-Valiñas, F. González-Gómez, A.J. PicazoTadeo, Utilities Policy, 24, 59-69 (2013)

11. A.V. Ermishina, Innovative Development of Russia's Economy: Regional Diversity: The Sixth International Conference, 524-532 (2013)

12. A. Rodionov, S. Sivaev, Journal of the head and chief accountant, 10, 52-53 (2011).

13. MUP Gorvodokanal. http://www.gorvodokanal.com/

14. MUP Vodokanal. http://www.vodokanalekb.rf/

15. OJSC Nizhegorodskiy vodokanal. http://www.vodokanal$\underline{\text { nn.ru }}$

16. MUP Vodokanal. http://www.kznvodokanal.ru

17. LLC Samara Utility Systems. http://samcomsys.ru/

18. MUP POVV. http://voda.uu.ru/

19. OJSC Omskvodokanal. http://www.omskvodokanal.ru/

20. OJSC PO Vodokanal. http://vodokanal.rnd.ru/

21. MUP Ufavodokanal. http://www.ufavodokanal.ru/

22. LLC. KrasKom. http://www.kraskom.com/

23. LLC Novogor-Prikame. http://www.novogor.perm.ru/

24. MUP (Municipal Unitary Enterprise). http://www.mupgvv.ru/

25. LLC RKS-Voronezh. http://www.voronezh-rvk.ru 